\title{
O MOVIMENTO INICIAL DE EXPANSÃO E FIXAÇÃO DAS NOVAS RELIGIÕES JAPONESAS NO BRASIL (1908-1940)
}

\author{
Fábio Marcelo de A. Melo Júnior ${ }^{1}$
}

\begin{abstract}
Resumo: O Brasil no início do Século XX recebeu uma onda de imigrantes japoneses que se instalaram, trouxeram novos costumes e religiões para o território brasileiro. $O$ presente trabalho procura compreender como se deu o movimento inicial de expansão e fixação das novas religiões japonesas no Brasil, desse modo entender como religiões do Japão, que possuem um contexto e uma dinâmica completamente diferentes, começam a se estabelecer e se desenvolver no Brasil. Para isso, serão abordadas questões referentes a conjuntura de surgimento dessas religiões no Japão, no fim do período de Shogunato dos Tokugawa (1603 - 1868), e na transição para a restauração Meiji (明治時代), em 1868 1912. Também será discutido o caráter missionário próximo ao pentecostalismo dessas novas religiões japonesas no Brasil. Assim como as diferenças de práticas religiosas entre o catolicismo e as novas religiões japonesas que ajudam a trazer mais adeptos para essas crenças estrangeiras.
\end{abstract}

Palavras-chave: Novas religiões japonesas; Brasil; Japão.

\begin{abstract}
The Brazil in the early 20th century received a wave of Japanese immigrants who settled, brought new customs and religions to the Brazilian territory. The present study seeks to understand how the initial movement of expansion and establishment of new Japanese religions in Brazil and thereby understand how religions of Japan, which has a completely different dynamic and context begin to establish and develop in Brazil. To do so, will be addressed issues relating to the context of emergence of these religions in Japan, at the end of the Shogunate of Tokugawa period (1603-1868), and in the transition to the Meiji Restoration (明治時代), 1868-1912. Will also be discussed next the missionary character of these new Japanese religions Pentecostalism in Brazil. As well as the differences in religious practices between Catholicism and the new Japanese religions help to bring more fans to these foreign religions.
\end{abstract}

Key-words: New Japanese Religions; Brazil; Japan.

\section{Introdução}

Em 1838, durante o Shogunato Tokugawa (período de governo militar da família Tokugawa), no Japão, surge a primeira religião que posteriormente será categorizada de shin-shûkyô (新宗教) ou Novas Religiões Japonesas. Em um contexto de transformações sociais internas e externas para o Japão, um novo movimento religioso plural vai ganhando vida. Enquanto o Budismo e o Shintoísmo (神道) não conseguem se renovar, as novas religiões vão surgir renovando as crenças japonesas, desse modo, ganhando espaço lentamente na sociedade japonesa.

\footnotetext{
${ }^{1}$ Estudante de Licenciatura em História na Universidade Federal de Pernambuco. Contato: Rua Professor Manoel de Almeida Belo, Bairro Novo, CEP: 53030030, Olinda-PE, Brasil. E-mail: faabio.melo@hotmail.com.
} 
O Shogunato Tokugawa fora o período pós batalha de Sekigahara (1600), onde com a vitória de Ieyasu Tokugawa sob os outros senhores da guerra japoneses, foi instituído o governo militar pelo vitorioso. Esse regime isolou relativamente o Japão por mais de dois séculos e meio. As políticas adotadas pelo Bakumatsu (termo para se referir ao período final do Shogunato dos Tokugawa) provocaram um contexto que terminou com a decadência do mesmo, de modo que com a Restauração Meiji (明治時 代), torna-se possível a volta da família imperial. O isolacionismo do Shogunato o privou de modernizar-se enquanto o mundo estava em um processo de modernização acelerado.

Sendo uma sociedade com a hierarquia rígida, comandada por um chefe militar, o Japão percebeu que a única alternativa seria sair do isolamento que vivia, após a investida dos Estados Unidos no porto de Edo (atual Tóquio). A abertura de portos não agradou a todos, e as medidas tomadas para controlar essa abertura acabaram criando um clima de tensão, que gerou assassinatos, revoltas, e tratados comerciais. ${ }^{2}$

A chegada das Novas Religiões Japonesas no Brasil se deu através da imigração para as colônias cafeeiras de São Paulo. Inicialmente não houve o interesse em divulgar as religiões japonesas no Brasil, pois para os japoneses, eles emigrariam para o Brasil por pouco tempo. Seria apenas um período curto onde eles acumulariam riquezas, e voltariam para o Japão economicamente melhor. Porém, como aponta Mori, ao chegarem nos trópicos, aos poucos perceberam que o trabalho poderia não ser de curto prazo, mas a longo prazo, pois o que recebiam trabalhando nas colônias de café era suficiente apenas para sua subsistência, e não era possível o acúmulo. ${ }^{3}$

Assim, permaneceram mais do que o planejado inicialmente, procurando formar comunidades e praticar suas religiosidades, porém, encontraram uma forte repressão por parte da Igreja Católica. Além dos primeiros anos, o governo Japonês orientou os imigrantes a evitar praticas religiosas, e caso acontecessem, que fossem de modo

\footnotetext{
${ }^{2}$ MCMASTER, John. "Alcock and Harris". Foreign Diplomacy in Bakumatsu Japan. Monumenta Nipponica, Tokyo, Vol. 22, No. 3/4 (1967), p. 326.

${ }^{3}$ MORI, K. "Vida religiosa dos japoneses e seus descendentes residentes no Brasil e religiões de origem japonesa". In: Uma epopéia moderna - 80 anos da imigração japonesa no Brasil, São Paulo: Hucitec Sociedade Brasileira de Cultura Japonesa, 1988, p. 561.
} 
singelo. Assim, as Novas Religiões Japonesas adentram do Brasil inicialmente sem a intenção de missões, como as práticas espirituais do cotidiano dos Imigrantes. ${ }^{4}$

Na década de 1920 houve o desenvolvimento de uma estrutura religiosa mais complexa, com a Igreja católica criticando tais práticas e tentando penetrar nas comunidades nipônicas. Contudo, Mori aponta que, mesmo com a repressão e as prisões, os adeptos continuaram a cultuar suas religiões, e a divulgar suas crenças de maneira singela. Encontraram dificuldades no caminho da divulgação, como a língua, os conceitos e vivências, mas tais dificuldades não foram impedimentos ao surgimento de novos adeptos, sendo estes japoneses ou não.

Na década de 1930 com o movimento um pouco mais solido, chegaram os novos missionários ao Brasil, o que fortaleceu a comunidade à medida que templos, igrejas e casa de divulgações foram construídas. Neste contexto, uma parcela dos brasileiros perceberam que o catolicismo conservador não se renovava aos tempos modernos em que estavam, enquanto as Novas Religiões apresentavam essa renovação. Este fator tornou as religiões japonesas no Brasil atrativas. ${ }^{5}$

De acordo com Mori, durante a Segunda Guerra Mundial a Igreja Católica conseguiu prender missionários japoneses com a justificativa de espionagem, o que prejudicou o desenvolvimento do que vinha sido construído até então. Porém, as shinshûkyô (新宗教) continuaram sua divulgação e seu movimento de expansão no Brasil.

\section{Surgimento das novas religiões japonesas}

As Novas Religiões Japonesas ou shin-shûkyô (新宗教) surgiram a partir do Séc. XIX, no fim do Shogunato dos Tokugawa (1603 - 1868) e início da Restauração Meiji ( 明治時代), em 1868 - 1912. É um momento de grandes transições internas e externas para o Japão, pois o Shogunato Tokugawa ou como também pode ser chamado, Bakufu (徳川幕府), durou duzentos e sessenta e cinco anos. Sendo um regime militar governando de políticas isolacionistas e para manutenção da estrutura do Shogunato. Durante a Restauração Meiji (明治時代) uma nova política ligada a modernidade foi

\footnotetext{
${ }^{4}$ Idem, p. 563.

${ }^{5}$ YAMADA, Masanobu. "A Concepção Vitalista da Salvação" no Brasil: As Novas Religiões Japonesas e o Pentecostalismo". In: Revistas de Estudos da Religião. São Paulo, no 3; 2004. Tradução: Kleber Maia Marinho, p. 47.
} 
colocada em prática, proporcionando relações com países que se distanciavam devido ao isolamento vigente durante o bakufu.

No decorrer do Shogunato Tokugawa, o Japão foi governado pela família Tokugawa, onde quem governava o Estado era o Shogun (将軍), sendo ele o chefe dessa família. Embora tenha sido um período em sua maior parte estável e pacífico, alguns pesquisadores como Ronan Alves Pereira apontam que houve momentos de revoltas e insatisfação da população, como aborda:

... também foi assolada por inúmeras revoltas camponesas. Por um lado, uma carga pesada de impostos, o controle social rigoroso, políticas administrativas ineficientes e a corrupção governamental, e, por outro lado, secas frequentes, colheitas fracassadas e fome: tudo isso levou periodicamente os camponeses à beira do desespero. ${ }^{6}$

O Japão Tokugawa estava dividido em vários domínios feudais, chamados de han (藩- território), cada han era administrado por um daimyo (大名), que eram proprietários de grandes territórios, tendo sua importância através da quantidade de produção de arroz. A hierarquia do Bakumatsu (幕末) consistia no Shogun (将軍) acima de todos, daimyo (大名) abaixo do Shogun (将軍), samurais, os trabalhadores camponeses, e mais abaixo estavam os artesãos e mercadores. A família imperial japonesa continuou a existir, porém, o papel que esta desenvolve no período é mais figurativo do que de fato governamental. Um dos grandes fatores que apontam isso é a família imperial viver em Kyoto, e o Shogun (将軍) estabelecer Edo (atual Tóquio) como a capital. ${ }^{7}$

O Bakumatsu (幕末)utilizou diversas leis para manter a ordem e a manutenção de seu governo, entre elas a que o daimyo (大名) teria que residir alternadamente a cada ano em Edo e na sua propriedade. Contudo, como aponta Romulus Hillsborough, três leis se sobressaíram nesse contexto, a primeira foi a proibição de criação de embarcações marítimas, o isolacionismo (com exceção da China e da Holanda), e o banimento do cristianismo.

\footnotetext{
${ }^{6}$ PEREIRA, Ronan Alves. Possessão por espírito e inovação cultural: a experiência das japonesas Miki Nakayama e Nao Deguchi. São Paulo: Aliança Cultural Brasil-Japão, Massao Ohno/Editores, $1^{\text {a }}$ edição, 1992, p. 2.

${ }^{7}$ HILLSBOROUGH, Romulus. Samurai Revolution: The Dawn of Modern Japan Seen Through the Eyes of the Shogun's Last Samurai. Tokyo: TUTTLE, 2014, p. 14.
} 
A vida religiosa durante o Bakumatsu (幕末) estava diretamente ligada ao budismo e ao Shintoísmo (神道), que eram as duas religiões aceitas pelo Shogun (将軍 ), e já estabelecidas no Japão, assim chamadas de Kisei Shûkyô (religiões estabelecidas). Porém, em 1838 surgiua primeira crença do movimento das novas religiões japonesas, a Tenrikyo(天理教). Ronan Alves Pereira aponta que:

No final do período Tokugawa, quando as religiões tradicionais (Budismo e Xintoísmo) tinham suas forças criativas já em desvanecimento, prevalecia a atmosfera de um generalizado desejo pela "renovação do mundo" entre o povo comum. Esta "sensação de não se estar vivendo bem nas circunstâncias em que se encontra" levou muita gente a buscar uma solução nos movimentos religiosos populares. ${ }^{8}$

Nota-se então a inabilidade das religiões estabelecidas de não se renovarem naquele período, o que abriu caminho para as Novas Religiões Japonesas, apesar das shin-shûkyô (新宗教) trazerem diversos elementos das religiões tradicionais.

O termo shin-shûkyô (新宗教)é um conceito em discussão, pois alguns autores utilizam o termo shinkô-shûkyô (新興宗教 - religiões surgidas recentemente), entretanto, Norbeck aponta que tal debate inicia-se no âmbito da imprensa:

Diz-se que o termo shinkô-shûkyô foi cunhado pela imprensa depois da Segunda Guerra. Uma vez que denota "religiões surgidas recentemente", com doutrinas pobres e muito mais preocupadas com a obtenção de "benefícios terrestres", este termo tende a ser substituído por shin-shûkyô. A própria União das Novas Religiões do Japão (Shin Nippon Shûkyô dantai Rengô-kai) tem promovido o uso do termo shin-shûkyô, por ser mais neutro e menos associado ao sentido pejorativo de shinkô-shûkyô (cf. Oishi et al. 1964:48). É preciso dizer, no entanto, que o eventual desprezo de muitos japoneses para com as Novas Religiões se justifica por inúmeros escândalos e acusações de atos ilegais envolvendo algumas denominações religiosas. ${ }^{9}$

Embora exista tal discussão de conceito nos termos, ambas denominações explicitam religiões populares surgidas a partir do Séc. XIX, tendo a Tenrikyô como precursora em 1838. Essas religiões sofreram grande perseguição do Bakufu Tokugawa (徳川幕府), pois eram vistas como seitas, algumas possuíam aspectos xamânicos, e não eram praticadas pelo Shogun (将軍). ${ }^{10}$ Desse modo, líderes das religiões foram presos, tiveram cultos proibidos, e várias outras maneiras de repressão.

\footnotetext{
${ }^{8}$ PEREIRA, Ronan Alves. Possessão por espírito e inovação cultural. Op. cit., p. 2.

${ }^{9}$ Idem, p. 1.

${ }^{10}$ Idem, p. 26.
} 
No Japão do Shogunato Tokugawa não houve uma única vertente de como deveria agir em relação abertura dos portos. Houve apoiadores do isolacionismo, como também houve aqueles que desejavam a abertura dos portos, pois acreditavam que essa abertura era necessária para se modernizar especialmente quando as experiências de guerra na China e Inglaterra mostravam a necessidade de modernização. ${ }^{11}$ Era uma teia de interesses que por vezes mudava, como samurais que apoiavam o isolacionismo, mas depois alguns acreditam que era necessário enviar pessoas para outros países para aprender e aperfeiçoar em prol do Japão.

O fim do bakufu (徳川幕府) teve início com a investida dos Estados Unidos no porto de Edo. Sem a permissão do Shogun (将軍), um navio estadunidense aportou com o Comodoro Matthew Perry e um grande arsenal de armas e tentou estabelecer relações com o Japão. Porém, inicialmente o Bakumatsu (幕末) fez promessas que se prolongaram até o momento que o diplomata estadunidense faz reais ameaças. A partir de então o Japão começou o movimento de fim do isolacionismo para além da China e Holanda $^{12}$, iniciou relações com os Estados Unidos e Inglaterra.

Com estabelecimento de relações com França, Inglaterra, Estados Unidos, o Shogun (将軍) impõe algumas medidas comerciais que descontentam a classe camponesa e aos estrangeiros que fazem comércio no Japão, ao passo que diplomatas e cidadãos estrangeiros foram mortos.

A Restauração Imperial Restauração Meiji (明治時代) ganhou cada vez mais força no Japão, chegando ao fim do Bakumatsu (幕末) e do Período Edo em 1868, onde o Imperador retomou o governo japonês, abrindo as portas do Japão para a modernização advinda do ocidente. Durante a Restauração Meiji (明治時代) também, houve uma série de revoltas, porém, todos os problemas foram contornados a medida que procuraram incorporar questões do ocidente sem perder o caráter nipônico. Assim, o Japão fortaleceu seu caráter nacionalista, criou Universidades e investiu em educação através do edito Imperial Educacional de 1890. A abertura para o ocidente e para novos princípios é uma questão fundamental para entender o movimento de chegada das shinshûkyô (新宗教) no Brasil.

\footnotetext{
${ }^{11}$ MCMASTER, John. "Alcock and Harris". Foreign Diplomacy in Bakumatsu Japan. Monumenta Nipponica, Tokyo, Vol. 22, No. 3/4 (1967), p. 345.

${ }^{12}$ HILLSBOROUGH, Romulus. Samurai Revolution. Op. cit., p. 23.
} 


\section{Chegada das Novas Religiões no Brasil}

O movimento de chegada das Novas Religiões Japonesas no Brasil se deu na década de 1920, inicialmente com a introdução de japoneses nas fazendas de café como colonos. Porém, nesse primeiro momento, não houve finalidade de missão religiosa na imigração dos japoneses para o Brasil. O objetivo da maior parte do povo nipônico era o de acumular riquezas e depois retornar ao Japão; seriam como convidados no Brasil, pois passariam pouco tempo. Assim, não havia a intenção de missões religiosas neste período. $^{13}$

Os japoneses não foram a primeira experiência imigratória da Ásia que o Brasil vivenciou. Antes de ocorrer a imigração japonesa, o Brasil experimentou com os chineses em 1880. Devido a existência da escravidão era difícil trazer europeus para trabalhar no Brasil, pois estes já tinham adotado o caráter abulicionista. Contudo, havia a necessidade de mão de obra com urgência, mesmo que o caráter da vinda ao Brasil fosse efêmero. Deste modo, houve a tentativa de imigração com chineses, que muitas vezes estava ligada ao tráfico de pessoas, mesmo com a envestida do governo chinês de impedir que acontecesse..$^{14}$

Porém, a experiência chinesa fracassou, pois estes eram vistos como "indolentes, sujos, racialmente inferiores, de pouca confiança, fracos e de um país derrotado", visto que a China perde para o Japão a guerra Shino-Japonesa, em 1895. Enquanto a China estava em uma de suas maiores crises, o Japão estava em plena ascensão, tendo uma política militarista-expansionistas, e aspectos ocidentais que conseguiu incorporar devido a reabertura após mais de duzentos anos de isolacionismo.

Internacionalmente o Japão ganhou projeção, com a anexação do arquipélago de Okinawa (1872), a vitória sobre a China (1895), e sobre a Rússia (1905). Pouco a pouco a terra do sol nascente foi se transformando em uma potência. Tal ascensão fez com que o Japão que antes era visto sem muito potencial, como afirma Rogério Dezem: "Em 1881 o periódico Japan Herald publicava em suas páginas que "os japoneses são uma raça alegre e, contentando-se com pouco, não parece que conseguirão muito." 15 Passasse a ser visto como o "Perigo Amarelo" no Ocidente, continua Dezém:

\footnotetext{
${ }^{13}$ DEZEM, R. Matizes do "amarelo": a gênese dos discursos sobre os orientais no Brasil (18781908). São Paulo: Associação Editorial Humanitas, 2005, p. 8.

${ }^{14}$ Idem, p. 10.

${ }^{15}$ Idem, p. 5 e 141.
} 
... em pouco mais de uma década os japoneses eram vistos sob o prisma de "Perigo Amarelo" (gelb Gefahr), denominação usada pela primeira vez na Europa pelo Kaiser Guilherme II da Alemanha ao "advertir" os russos sobre a expansão nipônica pela Asia. ${ }^{16}$

O fim da monarquia e da escravidão no Brasil mudaram o contexto migratório brasileiro, e a República pode se dedicar a trazer os japoneses ao Brasil. O interesse pelo povo japonês se deu pela ascensão do Japão, pois esta provocou o imaginário (local com a ideia de) que eram um povo trabalhador, dócil e barato, enquanto os chineses continuavam sendo vistos como indolentes, fracos, e de raça inferior. ${ }^{17}$

Essa dualidade entre o imaginário sobre o povo chinês e o povo japonês ficou evidente quando o governo brasileiro decidiu interromper as tentativas de relação com o governo chinês, e começou a tentar estabelecer relações com o Japão. Desse esforço, surgiu o Tratado de Amizade, comércio e navegação, assinado em 1895.

Com o início da imigração japonesa no Brasil, houve um momento de exotismo, pois o povo brasileiro não conhecia o Japão, e quando os japoneses chegam em território brasileiro, houve uma ação da imprensa, cartunistas, desenhistas que ajudou e solidificou a criação de mitos sobre os nipônicos. Esses mitos inicialmente os ligavam aos chineses, como cartuns que antes utilizavam a trança para abordar sobre os chineses também vão utilizar abordando os japoneses, o que provoca a ideia que todo o ideário que antes era atribuído aos chineses, como fracos, preguiçosos, sujo, fosse também atribuído ao japonês, ${ }^{18}$ como aponta Dezém.

Após a vitória do Japão sobre a Rússia na Guerra Russo-Japonêsa (1905), houve um movimento de interesse maior pelo Japão, visto como a "Ameaça Amarela", as representações dos japoneses começaram a mudar no Brasil, passa a ter um caráter mais rico, delicado, e honroso.

No início do Séc. XX o Brasil era um país majoritariamente católico, houve religiões africanas, de matizes africanas, ou outras experiências como o espiritismo, que teve sua origem na França. E essas experiências para além do catolicismo, irão ajudar e facilitar a aceitação e a incorporação de novos adeptos para as Novas Religiões Japonesas, pois apesar do catolicismo conservador, há uma pluralidade religiosa instalada no Brasil.

\footnotetext{
${ }^{16}$ Ibidem.

${ }^{17}$ Idem, p. 6.

${ }^{18}$ Ibidem.
} 
Nos primeiros anos não houve a inserção de religiões japonesas no Brasil (mesmo que o Brasil já tivesse o espiritismo e religiões de matriz africana, como Ubanda, e Candomblé) isso se deve, como já abordado, ao pensamento do povo japonês que seria um período de curta duração, e por isso não havia razões para estabelecer igrejas, templos, santuários, de qualquer religião japonesa no Brasil.

Porém, logo nos primeiros anos, os imigrantes perceberam que não seria algo de curto período, uma vez que o trabalho anual só estava permitindo a sobrevivência da própria família, sem juntar a quantidade de dinheiro que estavam visando. Essa percepção de que seria um trabalho de longa duração fez com que os japoneses começassem a formar colônias. ${ }^{19}$

A ideia de trabalho a longo prazo não mudou a intenção de ser um trabalho temporário, os imigrantes japoneses ainda almejavam a volta para o Japão. Eles eram constituídos principalmente de segundos e terceiros filhos que vinham para o Brasil, e seu objetivo, além de acumular riqueza, era melhorar as condições de vida para sua famíia, pois havia no Japão o costume dos primogênitos seguirem como chefe da família (seguindo o mesmo caminho do chefe anterior), e os demais irmãos iam constituir uma família própria. Atrelado a isso, o governo japonês fez uma forte campanha promovendo a emigração para a América do Sul, com vários cartazes, dizeres como "Vamos lá! Vamos levar nossas famílias para a América do Sul". ${ }^{20}$

Quando os imigrantes japoneses perceberam que a vinda ao Brasil seria a longo prazo, o desejo religioso começou a surgir. Houve a impossibilidade de praticar a religião do modo que era praticado no Japão (abarcando todas as religiões japonesas). $\mathrm{O}$ culto aos antepassados, que estava presente em quase todas as religiões japonesas, começou a ser feito dentro de casa, com um pequeno altar com fotos, ou em uma prateleira. Contudo, o governo japonês tinha se posicionado pedindo para que cultuassem suas crenças de forma discreta, pois não pretendiam ferir a supremacia brasileira. Sobre isso Noda aborda:

\footnotetext{
${ }^{19}$ MORI, K. "Vida religiosa dos japoneses e seus descendentes residentes no Brasil e religiões de origem japonesa". Op. cit., p. 564.

${ }^{20}$ Pôster de recrutamento promovendo a emigração japonesa para a América do Sul, ca. 1925. O recrutamento foi conduzido pela Overseas Development Company (Kaigai Kogyo Kabushiki Kaisha), estabelecida em 1917 para enfrentar as severas restrições impostas à imigração japonesa aos Estados Unidos. (Coleção do National Diet Library of Japan)
} 
... Os patrícios que emigraram para o Brasil devem ter sempre em mente que a grande maioria dos brasileiros é católica, devendo os cultos do budismo ou xintoismo, religiões estranhas para os brasileiros, serem realizados de maneira a mais discreta possível, e deixar de lado construções de templos budistas ou xintoístas que podem dar muito na vista. Considero essas medidas mais inteligentes para o desenvolvimento futuro de nosso povo. ${ }^{21}$

$\mathrm{Na}$ década de 1920 algumas religiões do movimento das shin-shûkyô (新宗教) ainda estavam surgindo. O Japão é oficialmente shintoista neste momento, e tem um forte sistema repressor com religiões que não são ramificações do Shintoísmo (神道). As Novas Religiões Japonesas são vistas como seitas, religiões que dentro do próprio Japão não são reconhecidas como religiões inicialmente, assim, sendo cultuadas ilegalmente. ${ }^{22}$

Durante o bakufu (徳川幕府), a religião oficial do Japão era o budismo. Ele servia como braço para a manutenção do regime, através de vários decretos estabelecidos pelo governo, o budismo controlava uma série de informações sobre a população. Registros de nascimentos é um exemplo, pois durante o bakumatsu (幕末) os templos budistas eram encarregados de registrar os novo membros da familia, além de cada família ser afiliada a um templo budista. Próximo ao budismo há o Shintoísmo ( 神道), que neste momento traçava um caminho entrelaçado com o budismo, onde cultuava-se os dois, os kamis (神) e os budas. Porém, com a Restauração Meiji (明治時 代), o shintoísmo (神道) se torna a religião oficial japonesa e ganha novas funções estatais. $^{23}$

Durante o período que o shintoísmo (神道) e o budismo exerceram o papel de religiões oficiais do Japão, não havia espaço legal para outras religiões que não fossem ramificações deles surgirem. A repressão com as outras religiões foi intensa, prendendo líderes, confiscando objetos de rituais, ou com visitas dos sacerdotes budistas e shintoístas para repreender abertamente. Para serem reconhecidas legalmente, as Novas

\footnotetext{
${ }^{21}$ MORI, K. "Vida religiosa dos japoneses e seus descendentes residentes no Brasil e religiões de origem japonesa”. Op. cit., p. 564.

${ }^{22}$ STRAELEN, Henry van. "The Religion of Divine Wisdom: Japan's Most Powerful Religious Movement”. In: Folklore Studies, Nanzan University, Vol. 13 (1954), p. 42.

${ }^{23}$ HARDACRE, Helen. "Creating State Shinto: The Great Promulgation Campaign and the New Religions”. Journal of Japanese Studies, Vol. 12, No. 1 (Winter, 1986), p. 56.
} 
Religiões Japonesas passaram a identificar-se como ramificações do budismo ou shintoísmo (神道). ${ }^{24}$

Naquele momento as shin-shûkyô (新宗教) não eram reconhecidas para além de seitas, sofreram uma forte repressão para adentrar no Brasil, como é o caso de pregadores da Tenrikyo (天理教) que, ao chegar em território brasileiro, sem estar em missão, necessitou assinar uma declaração com o governo japonês afirmando que não trabalhava na difusão no território brasileiro. Enquanto no Brasil, houve a perseguição aos imigrantes japoneses que não vieram na condição de pregadores de religião. Porém, decidem fazê-lo e acabam sendo presos, como é o caso de seguidores da Omoto (大本), uma Nova Religião Japonesa, que em Minas Gerais foram presos por suas atividades religiosas. ${ }^{25}$

Dentro da série de fatores já mostrados que dificultam o envio de missões religiosas, houve um ponto central que é a extensão do território brasileiro, pois as shinshûkyô (新宗教) não possuíam estruturas suficientes para cobrir os gastos que seriam empregados em uma investida religiosa no Brasil. Algumas das Novas Religiões ainda estavam surgindo, como a Perfect Liberty, enquanto outras já estavam estabelecidas, como é o caso da Tenrikyo (天理教) e da Omoto(大本), mas em nenhum dos casos conseguiriam suprir os custos necessários para mandar missões religiosas para o Brasil, pois devido à grande extensão do território, a quantidade de missionários seria elevada, juntamente com a quantidade de templos, igrejas, material de divulgação. Assim, a vida religiosa no período inicial era pouca, sendo feita mais comumente nos rituais aos ancestrais e em ocasiões fúnebres. ${ }^{26}$

Ainda na década de 1920, houve o movimento de êxodo urbano em São Paulo, onde os imigrantes japoneses saíram dos trabalhos do meio rural para morar na cidade em busca de melhores oportunidades de trabalho, visto que percebiam a necessidade de ficar um longo prazo no Brasil, mas também em busca de melhor educação para os filhos. $\mathrm{O}$ movimento de êxodo urbano deu origem às colônias japonesas urbanas, onde o maior exemplo é o Bairro da Liberdade em São Paulo, que começa sua formação na década de 1910. As colônias urbanas promoveram um ambiente mais propício para

\footnotetext{
${ }^{24}$ PEREIRA, Ronan Alves. Possessão por espírito e inovação cultural. Op. cit., p. 198.

${ }^{25}$ MORI, K. "Vida religiosa dos japoneses e seus descendentes residentes no Brasil e religiões de origem japonesa". Op. cit., p. 570.

${ }^{26}$ Ibidem.
} 
atividades religiosas, principalmente do shintoísmo (神道) e budismo, questão que já era compartilhada das colônias rurais, mas se fortalece no urbano, como aponta Mori.

As religiões japonesas não podiam fazer divulgações abertas, pois havia perseguição. Por outro lado, as estruturas religiosas brasileiras foram agressivas nas suas investidas missionárias com os imigrantes japoneses. Estabeleceram igrejas cristãs dentro das colônias japonesas, encontrando na década de 1910 uma comunidade que estava distante para pregar. Porém, o maior problema enfrentado pela igreja católica dentro das colônias (será o mesmo que as shin-shûkyô enfrentam), era a língua, pois os imigrantes não falavam português, e os missionários católicos não falavam japonês. Dado esse problema, a Igreja brasileira solicita ao Vaticano padres do Japão, para que seja possível a divulgação, como mostra K. Mori:

No mesmo ano o padre Lourencio, do Mosteiro da Penha, em São Paulo, vendo o aumento do número de imigrantes japoneses, solicitou ao embaixador do Vaticano acreditado no Rio de Janeiro o envio de um padre japonês. Em 1923 chegava ao Brasil o padre Chohachi Nakamura, nascido em Amamiôshima. Em 1926, o jesuíta Guido Del Toro ficou encarregado da catequese dos japoneses e no -dia comemorativo da Proclamação da República desse ano celebrou o batismo coletivo de 46 crianças descendentes de japoneses. ${ }^{27}$

\section{Criando raízes}

O movimento de divulgação das Novas Religiões Japonesas, que começara de forma singela com fieis fervorosos, ganhou maior espaço no fim da década de 1920 e início da de 1930, onde no interior de São Paulo elas fizeram um trabalho mais árduo. A Omoto (大本) já tinha começado a divulgação em Minas Gerais, como já citado, a Tenrikyo (天理教) em 1929 cria um núcleo em Bauru, através de 4 famílias, e em 1935 constroem o templo da religião.

A Seichô-No-Iê (生長の家) em 1930 já tinha começado sua divulgação através de fieis que liam as publicações em alguma colônias japonesas. Porém, as Novas Religiões Japonesas eram cultuadas apenas pelos imigrantes nipônicos e suas

\footnotetext{
${ }^{27}$ Ibidem.
} 
comunidades, sejam urbanas ou rurais. Isso se deu devido ao mesmo problema que a Igreja Católica brasileira enfrentou na missão das colônias japonesas. ${ }^{28}$

A língua foi o maior obstáculo para a divulgação além da comunidade japonesa no Brasil, onde mesmo quando o religioso sabia o português, houve termos que não tinham tradução para o português, o que causou uma forte rejeição dos brasileiros às shin-shûkyô (新宗教). Por outro lado, o japonês desde sua inserção no Brasil foi visto como algo exótico, principalmente após a vitória contra a Rússia, na Guerra RussoJaponesa em 1905, e seus elementos religiosos chamavam a atenção da população. ${ }^{29}$

As Novas Religiões começaram a ter estabilidade no Brasil, e com isso as divulgações aumentaram, porém, eram poucas, pois inicialmente as práticas religiosas e as divulgações eram quase nulas. O movimento de trazer novos adeptos aconteceu dentro da própria comunidade japonesa, entretanto, era muito limitado e as Novas Religiões expandiram para fiéis brasileiros, enfrentando problemas não apenas de idiomas, mas de vivências. Alguns conceitos, por exemplo, Hinokishin (日の寄進) da Tenrikyo (sendo a ideia de trabalhar voluntariamente com gratidão pelo que lhe é dado por Deus), que mesmo traduzidos não pareciam se encaixar na realidade brasileira para alguns novos adeptos. ${ }^{30}$ Por outro lado, as shin-shûkyô (新宗教), oferecem uma experiência que começa a atrair novos fieis, pois de acordo com Masanobu Yamada:

Quando indaguei aos novos adeptos da nova religião japonesa como sentiam a diferença das religiões que pertenceram antes, eles geralmente respondiam conforme os pontos, a seguir: (1) os rituais e os métodos de oração são originais e novos para eles. (2) os ministros e os adeptos mais antigos deram-lhes uma cuidadosa orientação, enquanto os padres católicos, por outro lado, eram relutantes ao envolvimento de seus problemas pessoais. Além disso, todos responderam que (3) a imagem que tinham de Deus havia mudado. Isto é, foram ensinados pela igreja católica, pela família e pela escola a cultivarem a Imagem de Deus como Aquele que pune os seres humanos, mas nas novas religiões, Deus é sentido mais intimamente, como o amor. Ademais, mencionaram que (4) conscientizaram-se de seu próprio ser divino ao serem libertados da noção de viver sob a opressão do pecado. Comparando com o catolicismo, o que se ressalta é a verdadeira natureza dos seres humanos na posição de divino e completamente perfeito, e a possibilidade de que eles podem unir-se e tornar-se um com Deus, a Vida Original. ${ }^{31}$

\footnotetext{
${ }^{28}$ Idem, p. 572.

${ }^{29}$ DEZEM, Rogério. Matizes do "amarelo". Op. cit., p. 08

${ }^{30}$ YAMADA, Masanobu. "A Concepção Vitalista da Salvação" no Brasil: As Novas Religiões Japonesas e o Pentecostalismo”. Op. cit., p. 30.

${ }^{31}$ Ibidem.
} 
Desse modo, vemos a inabilidade da Igreja Católica de renovar seus métodos, e conceitos fazendo com que os seguidores não se sintam satisfeitos com o que encontram.

Dentro das Novas Religiões, Yamada ainda verifica uma maior proximidade pessoal entre os seguidores e os membros mais antigos, ou o condutor da Igreja, como orientadores espirituais, enquanto não há esse contato pessoal com o padre. Outro ponto de grande importância é a figura de Deus, onde nas Novas Religiões Japonesas os fiéis se sentiram mais próximos dele, tendo ele como figura de amor. Ligado a isso temos em algumas das shinshûkyô, como a Tenrikyo (天理教), a denominação de Deus pai e mãe.

As Novas Religiões Japonesas tem questões em comum com o pentecostalismo (movimento religioso protestante que diverge do protestantismo tradicional, procurando a união com o espírito santo), diferindo em várias questões teológicas e práticas, mas possuindo algumas semelhanças como:

... o crescimento do pentecostalismo, que ocorreu em um contexto cristão é, com certeza, nitidamente diferente, tanto em relação ao tempo quanto ao espaço, do das novas religiões japonesas, que emergiram em um país predominantemente Budista. No entanto, há semelhanças entre as duas, tanto nas doutrinas e práticas, como nas estruturas salvíficas. Nas religiões históricas como o Cristianismo e o Budismo, a salvação e os benefícios deste mundo são tratados como metas religiosas conflitantes. Ainda assim, essas duas noções estão unificadas sem contradição em ambas: no Pentecostalismo e nas novas religiões japonesas. Também semelhante é o fato de que ambas sofreram a discriminação persistente das religiões como o Cristianismo e o Budismo. ${ }^{32}$

Além da estrutura de salvação, há a perseguição e discriminação praticadas pelo Budismo e Cristianismo. Com o início da Segunda Grande Guerra(1939 - 1945), a Igreja Católica brasileira se utilizou de artificios, como dos missionários das Novas Religiões Japonesas estavam exercendo função de espião para o Japão, para prender e repreender processos de divulgações das shin-shûkyô (新宗教), através do "Serviço Social de Assistência".

Um dos movimentos importantes realizados durante a guerra foi o "Serviço Social de Assistência", organizado principalmente pelos católi- cos. Com o advento da Segunda Guerra, os japoneses foram presos, como suspeitos de espionagem, e recolhidos à antiga Hospedaria dos Imigrantes. ${ }^{33}$

Sendo o caso, por exemplo, de Chujiro Ohtake, missionário da Tenrikyo (天理教 ) e dirigente do templo de Bauru, que fora preso, e resiste a sua fé, como mostra Mori:

\footnotetext{
${ }^{32}$ YAMADA, Masanobu. "A Concepção Vitalista da Salvação no Brasil: As Novas Religiões Japonesas e o Pentecostalismo". Op. cit., p. 31.

${ }^{33}$ MORI, K. "Vida religiosa dos japoneses e seus descendentes residentes no Brasil e religiões de origem japonesa". Op. cit., p. 574.
} 
Os templos foram fechados e as reuniões proibidas. No mês de março desse ano (1942), Chujiro Ohtake, dirigente do templo de Bauru foi preso na qualidade de um dos principais líderes dos japoneses e ficou detido durante um ano e três meses em São Paulo. Foi liberado em maio do ano seguinte, mas como estava proibido de sair da cidade de São Paulo, ficou hospedado na casa de pregação da Capital. Arrendou um terreno contíguo, e a pretexto de casa de treinamento, inaugurou secretamente uma escola de doutrinação, esforçando-se por formar fiéis qualificados, principalmente jovens de ambos os sexos. ${ }^{34}$

$\mathrm{Na}$ década de 1930, as shin-shûkyô (新宗教) começam as divulgações de maneira mais eficiente, através ações no meio urbano, limpando praças, conversando, publicando jornais da própria religião, assim como os mangás para contar suas histórias, promoção de cursos de teologia, de japonês. As Novas Religiões encontram uma forma que não era comum no Brasil ser utilizada, e consegue atingir uma quantidade relevante de pessoas.

\section{Considerações finais}

O movimento de entrada das Novas Religiões Japonesas no Brasil é marcado por repressões, resistências, e dificuldades relacionadas a um contexto completamente diferente do Japão, a um idioma que não é o japonês, além da vinda para o Brasil por parte dos imigrantes que esperavam uma realidade de curto prazo e por necessidade se torna a longo prazo, e mais a frente deixa de ser temporário para se transformar em fixo.

O presente artigo visou explicar o início da entrada das Novas Religiões Japonesas no Brasil, sem adentrar nas décadas de 1960 até 1980, que é o momento em que as shin-shûkyô (新宗教) conseguiram o maior número de adeptos, e se estabeleceram de modo sólido após a Segunda Guerra Mundial ter derrubado quase todo o esforço para consolida-las anteriormente no Brasil.

Percebeu-se que inicialmente houve uma concentração das Novas Religiões Japonesas no Sudeste, principalmente em São Paulo, mas atualmente há uma expansão no território brasileiro, estando essas religiões em todas as regiões do Brasil, porém, tendo um número mais relevante de adeptos ainda no sudeste do país.

As relações estabelecidas pelas Novas Religiões não foram algo uniforme, ou iguais entre elas. Cada uma surgiu em épocas distintas, em anos diferentes, com

\footnotetext{
${ }^{34}$ Ibidem.
} 
teologias diferentes, ações diferentes, organizações estruturais diversas, mas compartilham um mesmo processo que é o surgimento a partir do fim do Shogunato dos Tokugawa, e se popularizam como seitas, que sofrem repressão em um contexto em que apenas o Budismo e o Shintoísmo eram religiões reconhecidas.

\section{Referências Bibliográficas:}

ANDRÉ, Richard Gonçalves. Religião e silêncio: representações e práticas mortuárias entre nikkeis em Assaí por meio de túmulos (1932 - 1950). 2011. 250 f. Tese (doutorado) Universidade Estadual Paulista, Faculdade de Ciências e Letras de Assis, 2011.

DEZEM, Rogério. Matizes do "amarelo": a gênese dos discursos sobre os orientais no Brasil (1878-1908). São Paulo: Associação Editorial Humanitas, 2005.

HARDACRE, Helen. "Creating State Shinto: The Great Promulgation Campaign and the New Religions”. Journal of Japanese Studies, Vol. 12, No. 1 (Winter, 1986), pp. 29-63.

HILLSBOROUGH, Romulus. Samurai Revolution: The Dawn of Modern Japan Seen Through the Eyes of the Shogun's Last Samurai. Tokyo: Tuttle, 2014.

KASHIO, N. "The End of the Vitalistic Conception of Salvation: an Inquiry into Conceptual Validity in Modern Japanese New Religions". Religion and Society Special Issue - Records of the 2002 Workshops. Japan: JASRS, 2004, pp. 68-81.

MCMASTER, John. "Alcock and Harris. Foreign Diplomacy in Bakumatsu Japan". Monumenta Nipponica, Tokyo, Vol. 22, No. 3/4 (1967), pp. 305-367.

MATSUE, Regina Yoshie. "A Expansão Internacional das Novas Religiões Japonesas: Um Estudo sobre a Igreja Messiânica Mundial no Brasil e na Austrália". Revistas de Estudos da Religião. São Paulo, nº 4, 2002, pp. 1-19.

MORI, Koichi "Vida religiosa dos japoneses e seus descendentes residentes no Brasil e religiões de origem japonesa". Uma epopéia moderna - 80 anos da imigração japonesa no Brasil. São Paulo: Hucitec. Sociedade Brasileira de Cultura Japonesa, 1988, pp. 560-598.

NAKAYAMA, Yoshikazu. Minha Oyassama. Departamento de Missoes Ultramarinas da Tenrikyo, 1992.

PEREIRA, Ronan Alves. Possessão por espírito e inovação cultural: a experiência das japonesas Miki Nakayama e Nao Deguchi. São Paulo: Aliança Cultural Brasil-Japão, Massao Ohno/Editores, $1{ }^{\text {a }}$ edição, 1992, 198 p.

SHIMAZONO, Susumu (1991). "The Expansion of Japan's New Religions into Foreign Cultures". Japanese Journal of Religious Studies, 18/2-3, pp.105-132.

SHOJI, Rafael, USARKI, Frank. "Japanese New Religionsin Braziland the Dynamics of Globalization versus Glocalization”. Journal of Religion in Japan, Japan, № 3, pp. 247-268.

SHÕZEN Nakayama. "Contemporary Religions in Japan”. Vol. 4, No. 4 (Dec., 1963), Nara. Tenrikyo: the Path to Joyousness, Tenrikyo Overseas Mission Department, 1998, pp. 325-331.

STRAELEN, Henry van. "The Religion of Divine Wisdom: Japan's Most Powerful Religious Movement”. Folklore Studies, Nanzan University, Vol. 13 (1954).

TOMITA, Andréa. "Inovação Religiosa e Cultural no Processo de Transplantação das Novas Religiões Japonesas no Brasil”. Anais do II Simpósio sobre História das Religiões, 2000.

YAMADA, Masanobu. "A Concepção Vitalista da Salvação" no Brasil: As Novas Religiões Japonesas e o Pentecostalismo". Revistas de Estudos da Religião. São Paulo, no 3; 2004. Tradução: Kleber Maia Marinho, pp. 29-49. 
"Tenrikyo in Brazil from the Perspective of Globalization". Revistas de Estudos da Religião, São Paulo, march, 2010, pp. 29-49. 